\title{
UNDERSTANDING THE MIGRANT CRISIS IN BOSNIA AND HERZEGOVINA
}

\section{Kenan HODŽIĆ}

\section{Abstract}

Reasons for writing and research problem(s): The focus on migration processes has been dramatically intensified, both internationally and nationally. Often, this phenomenon undermines national and political unity. The inspiration for exploring this phenomenon was initially related to the local demarcations about the migrant crisis. People in the movement are becoming a more frequent occurrence in Bosnia and Herzegovina, and our country represents a transit destination to European countries, so it is essential to explain and shed light on the repercussions of this crisis and the (un)willingness of the state to respond to growing challenges that concern general public.

Aims of the paper: The scientific aim of this paper is reflected in the description of capacities in the conditions of the migrant crisis, taking into account the structure of the political and security system, and the relations and connections between these systems. The social aim of the paper is to present findings of the migrant crisis as a security and humanitarian risk with severe potential and to get acquainted with the key characteristics and risk factors arising from the migrant crisis.

Methodology/Design: Given the interdisciplinarity of this subject, to a greater or lesser extent, various general scientific methods are used, primarily the hypotheticaldeductive method and the analytical-deductive method, the method of scientific findings, and the method of analyzing the content of documents, events and testimonies in terms of analysis coordination and readiness of relevant actors in Bosnia and Herzegovina.

Research/paper limitation: Tracking migratory movements requires considerable resources, infrastructure and IT/knowledge systems, therefore B\&H's ability to collect, administer, analyze and report data on mobility, migration flow is often uneven and limited.

Results/Findings: In Bosnia and Herzegovina, different attitudes and approaches to the phenomenon of migrations are evident. In other words, authorities in Bosnia and Herzegovina do not apply harmonized migration policy.

General conclusion: Findings presented in this paper can contribute to a broader understanding of the framework of the dichotomy between the security (state- 
centric) approach and the humanitarian (human-centric) approach of the migrant crisis in Bosnia and Herzegovina.

\section{Key words}

migrant crisis, Bosnia and Herzegovina, institutional capacities, security approach, humanitarian approach

\section{INTRODUCTION}

The approach to researching this phenomenon will focus on two dimensions: the institutional capacity of Bosnia and Herzegovina (B\&H) observed through the structure of the political and security system, and state managing migration flows of the "Balkan route" passing through $\mathrm{B} \& \mathrm{H}$.

Migrations raise questions of human rights, international law and state sovereignty, and it is a hotly discussed, live and challenging issue in the contemporary politics of many states. The term "migrant" in this paper is used as a generic concept covering refugees, economic migrants and asylum seekers. Thus, the reason for which people choose to leave their countries and places of living has not been defined (war, economic conditions, coercion/voluntariness, environment degradation) (Internationl Organization for Migration - IOM, 2016). Refugees are persons who have left their countries of origin due to a well-founded fear of persecution, conflict, generalized violence or other circumstances that have seriously disturbed public order and, as a result, in need of international protection. ${ }^{1}$

The migration wave of refugees from war-torn areas of Asia and Africa, most commonly from Syria, Afghanistan and Iraq, culminated in the biggest refugee crisis of modern times. ${ }^{2}$ Generally, the use of the term crisis implies the expectation or possibility in principle of an ending, where normality is re-established. This may involve the restoration of the old status quo, or it may involve a wholesale transformation or selective reform/reorganization. Whatever their particular shape, however, crises are

\footnotetext{
1. The definition of refugees is set out in the 1951 Convention and regional instruments on refugees, as well as the UNHCR Statute.

2 These so-called mass migrations of a measured type (refugees, asylum seekers and economic migrants, victims of smuggling and trafficking in human beings, women and children and other categories of vulnerable persons without valid documents) (IOM, 2016) are labelled in Europe as a "refugee/migrant crisis".
} 
conventionally viewed as, by definition, an exceptional turn of events (Lindley, 2014, p. 2). The International Organisation for Migration, an inter-governmental organization, uses the term "migration crisis" to describe large-scale, complex migration flows due to a crisis which typically involves significant vulnerabilities for individuals and communities affected. A migration crisis may be sudden or slow in onset, can have natural or human-made causes, and can take place internally or across borders (IOM, 2012, p. 9). Also, the "Crisis Migration Project" focuses on movement in the context of humanitarian crises where there is a widespread threat to life, physical safety, health or bare subsistence that is beyond the coping capacity of individuals and the communities in which they reside (Martin et al., 2014, p. 5). In this paper, it will permeate two approaches which tend to foreground the vulnerabilities of people on the move, threats for communities and political-security systems in general.

A crisis of this type, which is still ongoing, has shown how much the process of globalization has changed the world picture in the last decade and how unprepared international institutions, whose main task is to protect human rights, are to face and solve more significant challenges, especially when it comes to a large number of human lives. Bobić and Šantić (2018) argue that Balkan region, characterized by the mass exodus of refugees in the 1990s, two decades later still retains the status of a significant "supplier" of the EU to some new migration flows, this time from more distant territories, and becomes a transit area.

It is evident that a large number of migrants, refugees and asylum seekers (people on the move) remained "stuck" in the countries of the Western Balkans at the time of writing, mainly due to restrictions on movement and other measures ${ }^{3}$ to reduce the spread of the COVID-19 coronary pandemic. ${ }^{4}$ The general epidemiological measures taken have closed the borders for all foreigners, including migrants, while some governments have introduced reduction measures aimed at migrants. ${ }^{5}$ Previous, as the issue of sovereignty and identity, was emphasized, some countries decided to erect large fences, ${ }^{6}$ which, due to the circumstances, turned the migrant route towards

3 Declaration of a state of emergency, ban on movement, curfew, ban on migrants leaving reception centres

${ }^{4}$ On March 11, 2020, the World Health Organization declared a pandemic of the Covid-19 coronavirus, which has spread to more than 180 countries around the world.

${ }^{5}$ The Belgian and German authorities, for example, have made decisions not to accept asylum applications (Mazzola and Martiniello, 2020).

${ }^{6}$ Bulgaria with Turkey in April 2015, Hungary with Serbia in September 2015, Macedonia with Greece in Novembar 2015, Slovenia with Croatia in Novembar 2015, Austria with Slovenia in 
Bosnia and Herzegovina. A large number of migrants are housed in reception centres, a specific part of them are housed in abandoned buildings in cities where reception centres are located, and a smaller part of people on the move who have financial resources have rented apartments or rooms in which they temporarily stay. They became trapped in $\mathrm{B} \& \mathrm{H}$, which is outside the Schengen area and had not been integrated into a comprehensive EU strategy. From 2018, Bosnia and Herzegovina, previously spared by the passage of migrants, has become a central crossing point on the Balkan route, due to the closure of neighbouring borders. Twenty-three thousand seven hundred fifty migrants were recorded in Bosnia and Herzegovina in 2018, compared to only 1,116 in 2017 (Terzić, 2018), told the director of Border Police of B\&H.

The two key questions raised in this paper are: do we have sufficiently well-designed efficient and sufficient institutional capacities to deal with the current humanitarian and security challenges of the migrant crisis and is it necessary to further strengthen Bosnia and Herzegovina's migration policy? The answers to these problematic questions will enable us to see the capacities but also the conditions that may harm the further development of this migrant crisis.

There was a continued increase in the number of migration-related academic publications, with the largest ever academic output produced during the last two years (IOM, 2020). So far, research about B\&H on the migrant and refugee crisis has been done but from the point of view of collecting statistics on the number of migrants, seeking international asylum, countries of origin of migrants, their final destinations, dealing with vulnerable categories, mostly women and children, children unaccompanied, and statistics on smuggling and trafficking in human beings, mostly by the UNHCR, IOM, OSCE, FRONTEX and others. However, in order to illustrate the framework and needs of the security and humanitarian approach of $\mathrm{BiH}$ migration policy, it is necessary to penetrate much deeper into the issue. It is worrying that people of unfortunate destinies have been pushed into life insecurity with a broader negative discourse that is increasingly taking on a bad connotation.

General attitudes toward immigration remain polarized, while hostile anti-immigration political rhetoric continues to take centre stage in several national elections across Europe (Diamant and Starr, 2018). A 2018 European Commission survey found that four in ten Europeans view immigration as more of a problem than an opportunity 
(European Commission, 2018b). In a separate survey conducted in 10 EU countries, ${ }^{7}$ by the Pew Research Centre, more than half of respondents said they want fewer immigrants in their countries (Connor and Krogstad, 2018). McAuliffe (2018) highlights that we are increasingly witnessing the harnessing of social media as a means of division and polarization, not just on migration, but at certain times we have seen the deployment of online "tribal tactics" by activists attempting to depict migration in a harmful and misleading light. Several analyzes of media reporting in B\&H show that a specific part of the domestic population is prone to negative perceptions of people on the move, where they are exposed to particular media criminalization. ${ }^{8}$ There are many examples of media that publish stereotypes and misinformation about migrants and refugees (UNHCR, 2018). According to Ahmetašević (2020), "the media in B\&H are more megaphones of the government than tools in the service of the public, and with their reporting and transmission of messages of intolerance, they helped spread panic and fear, which resulted in violence." In this regard, special attention should be paid to the possibility of resistance of the local population towards migrants and refugees and the possible escalation of the conflict with the local population (Maksimović, 2020), which could lead to mass protests by citizens. Sure, that rise of the negative attitude towards migration in the world leads to the unsuccessful implementation of good migration policies, which would make a positive contribution to the management of migration flows.

\section{SPECIFICS OF BOSNIA AND HERZEGOVINA IN THE STUDY OF MIGRATION MOVEMENTS}

The Constitution of Bosnia and Herzegovina ${ }^{9}$ is one of the most complex constitutional documents for which the international community gave its approval 25 years ago. It represents a decentralized model of how the state should be organized and transfers important jurisdictions and functions of the government to the two entities that make

7. The 10 EU countries surveyed included Greece, Hungary, Italy, Germany, Sweden, Poland, France, the Netherlands, the United Kingdom and Spain.

${ }^{8}$ Antimigrant is a radical website that publishes hate speech and misinformation about migrants and refugees in $\mathrm{BiH}$ and even calls for direct attacks on this population. Modus operandi is copying and transferring a member from other media about migrants and refugees with a change of title to sound provocations and discriminatory calls for direct attacks on migrants and those who help them. In addition to hate speech about migrants, antimigrant.ba publishes misinformation about specific persons, institutions and organizations that operate in $\mathrm{BiH}$ and help refugees and migrants (Sokol, 2019).

${ }^{9}$ The General Framework Agreement for Peace in Bosnia and Herzegovina signed on 14.12.1995. 
up $B \& H$, ie. The Federation of B\&H and the Republic of Srpska, but also leaves to state bodies administrations that are vital for the functioning of the modern state. Those two entities, ten cantons, and an autonomous region Brčko District have its governments. There is a separate government at the state level and a three-member presidency which indicate that complex political structure is one of the reasons believed to be hindering efforts to cope with the looming migrant crisis.

On the other hand, $\mathrm{B} \& \mathrm{H}$ is a country historically characterized by a high emigration rate, as evidenced by the latest World Migration Report (IOM, 2019) where, in addition to Lithuania and Latvia, B\&H experienced the worst population decline (more than $10 \%)$. Apart from two significant waves of emigration, labour migration in the 1960s and 1970s and forced migration caused by the war of the 1990s, B\&H continues to face continuous emigration of the domicile population, caused by the poor economic situation in the country (Ministry of Security BiH, 2016). In March 2016, the B\&H Council of Ministers adopted a migration and asylum strategy and action plan for 20162020. The strategy was prepared in the light of the implementation of the stabilization and association agreement (SAA) with the EU that had entered into force in June 2015. European Union is made up of countries that have a clear foreign policy of its own but seems that Union does not have a particular political force to respond jointly to the migrant crisis. ${ }^{10}$ Regarding that, Lhoumeaum (2019) thinks that crisis "placed the region high on the agenda, underlining the importance of the region strategically and security-wise" and EU showed a more profound will to engage in the region, by the reactivation of enlargement mechanisms and the implementation of cooperation mechanisms. On the other hand, migration routes are changing as migrants still want to reach European territory. The migration trends are essential since they point to broader problems involving political stabilization and the unfinished transition process in the Western Balkans (Bonifazi et al., 2014). As Vale (2018) pointed out: "the EU passes the buck to Bosnia and Herzegovina".

Further, it should be noted that the geographical position of $\mathrm{B} \& \mathrm{H}$ is specific because it is located at the crossroads from east to west, which makes it suitable for the transit of migrants on their way to European countries. The Migration Profile of $B \& H$ is a document that aims to provide insight into key trends in the field of migration, enable

${ }^{10}$ Different migration policies marked the migrant policy and served as either a positive or negative example to other countries in approaching this challenge. Tatalović and Malnar (2016) state that Germany, through the policy of guaranteeing the right to asylum and humane acceptance and treatment, has become attractive to migrants, which is a positive example, while Hungary with the policy of raising the fence on external borders is the opposite example. 
the development of quality policies and the adoption of appropriate regulations in the field of migration and asylum. The Ministry of Security of Bosnia and Herzegovina (2020) points out that in the fourth quarter of 2017, B\&H encountered mass illegal entry of migrants into its territory, and the trend of illegal entry intensified in 2018. and 2019. In the specified period, the competent authorities for the area of migration in $B \& H$, they identified the following routes that illegal migrants use most often to pass through B\&H: a) Greece - Albania - Montenegro - B\&H - Croatia and further towards other EU countries; b) Greece - Macedonia - Serbia - B\&H - Croatia and further towards other EU countries; c) Greece - Bulgaria - Serbia - B\&H - Croatia and further towards other EU countries. More precisely, data on illegal crossings and attempts at illegal crossings collected by the Border Police of B\&H in 2018, indicate widespread reception of entry, and there are three main movement directions of migrants: a) one from Serbia to Bijeljina; b) the second from Serbia towards Višegrad and Zvornik and c) the third from Montenegro towards Trebinje, Bileća and Gacko, lately also towards Foča (Institution of the Human Rights Ombudsman of Bosnia and Herzegovina, 2019).

\subsection{Institutional capacities for the migrant crisis}

Within the institutional framework for the migrant crisis in $B \& H$, we will analyze the key $\mathrm{B} \& \mathrm{H}$ institutions which, according to the Constitution, international law and domestic legal and by-law framework, represent responsible subjects and holders of migration policy. There are four ministries within the Council of Ministers of B\&H (Ministry of Security, Ministry of Civil Affairs, Ministry of Foreign Affairs and Ministry of Human Rights and Refugees), as well as some administrative organizations within the Ministry of Security of B\&H and a particular inter-ministerial body - Coordination Body for Migration in B\&H.

The Decision on the Establishment of the Coordination Body for Migration Issues in Bosnia and Herzegovina ${ }^{11}$ establishes an inter-ministerial body in charge of coordinating activities between competent institutions dealing with migration and asylum issues in B\&H. Leading civil and police officers from the Ministry of Security (Service for Foreigners, Border Police of B\&H, State Investigation and Protection Agency, Immigration Sector and Asylum Sector), Ministry of Human Rights and Refugees of B\&H have been appointed to the Coordination Body for Emigration and

11 Official Gazette of B\&H, No. 10/13, 64/13, 01/14, 20/16 and 83/17 
the Sector for Refugees, Displaced Persons, Readmission and Housing Policy) and the Ministry of Foreign Affairs (Sector for International Legal and Consular Affairs).

The Ministry of Security of $B \& H$ is one of the nine ministries within the Council of Ministers of B\&H as Law on the Council of Ministers prescribes (2008) in Art. 5. Its existence is not explicitly outlined in the B\&H Constitution. The Ministry of Security of $\mathrm{B} \& \mathrm{H}$ is responsible for: (1) protection of international borders, internal border crossings and traffic regulation at \&iH border crossings; (2) the prevention and detection of perpetrators of the offenses of terrorism, drug trafficking, counterfeiting of domestic and foreign currency and trafficking in human beings and other criminal offenses with an international or inter-entity element; (3) international cooperation in all areas within the jurisdiction of the Ministry; (4) protection of persons and objects; (5) collection and use of data relevant to the security of $\mathrm{BiH}$; (6) organization and coordination of activities of the Entity Ministries of Interior and the Brčko District of $B \& H$ in accomplishing security tasks in the interest of $B \& H$; (7) implementation of international obligations and cooperation in the implementation of civil protection, coordination of the activities of the entity civil protection services in B\&H and harmonization of their plans in case of natural or other disasters affecting the territory of $\mathrm{B} \& \mathrm{H}$ and adoption of protection and rescue programs and plans; (8) creates, takes care of and implements the policy of immigration and asylum in $\mathrm{B} \& \mathrm{H}$ and regulates the procedures related to the movement and residency of foreigners in $B \& H$; (9) regulate the procedures and manner of organization of the Service in connection with the movement and residency of foreigners in $\mathrm{B} \& \mathrm{H}$; (10) providing support to $\mathrm{B} \& \mathrm{H}$ police authorities; (11) education and professional development of staff in accordance with the needs of $\mathrm{B} \& \mathrm{H}$ police bodies and other offices and agencies in the field of security and (12) forensic examinations and expertise, as we see in Art. 14 of Law on Ministries and Other Administrative Bodies of B\&H (2009). Today, the Ministry of Security of B\&H consists of seven administrative organizations: (1) Directorate for Coordination of Police Bodies of B\&H; (2) B\&H Border Police; (3) State Investigation and Protection Agency; (4) Agency for Forensic Examinations and Expertise; (5) Agency for Education and Professional Development of Personnel; (6) Police Support Agency and (7) Service for Foreigners. The Ministry of Security of $B \& H$, in cooperation with other institutions and agencies, undertakes daily activities following the Action Plan of Emergency Measures and the conclusions of the Presidency of $\mathrm{BiH}$, the Council of Ministers of $\mathrm{BiH}$ and the Coordination Body for Migration in Bosnia and Herzegovina (Atlantic Initiative, 2020). The Service for Foreigners Affairs is an administrative organization within the Ministry of Security of B\&H, defined in Art. 2 of Law on Service for Foreigners Affairs (2008), with operational independence for conducting business and resolving issues within its jurisdiction. It was established to perform administratively, and inspection tasks prescribed by the Law on Asylum and more specifically deals with the activities 
of the movement, residency of foreigners, and asylum which also includes inspection supervision and control of the movement and residency of foreigners; conducting administrative proceedings to resolve applications for residence permits for foreigners; placing foreigners residing illegally in $\mathrm{B} \& \mathrm{H}$ under surveillance; deportation/return of foreigners who have been issued a final decision on removal; security checks of foreigners when deciding on the issuance of visas, collection of information on illegal migration and migrants.

At the headquarters of the Service, in addition to the Director, Deputy, and Assistant Directors, there are three primary organizational units - sectors: Sector for Operational Support, Sector for Administration, and Sector for Readmission, Reception, and Accommodation. The basic organizational units at the headquarters of the Service also include the Service of the Director, the Service for Strategic Planning, Analysis and Statistics, and the Service for Internal Control. In addition to the headquarters of the Service, there are also field centres that represent organizational units outside the headquarters of the Service. Field centres perform inspection supervision over the implementation of legal provisions that regulate the issues of movement, residence, and employment of foreigners and administrative-administrative tasks determined by the Law on Movement and residency of foreigners and Asylum. There are a total of 16 field centres located in cities and municipalities throughout B\&H: Sarajevo, Banja Luka, Mostar, Bihac, Tuzla, Trebinje, Zenica, Bijeljina, Brcko, East Sarajevo, Doboj, Travnik, Gorazde, Orasje, Livno and Ljubuski. In addition to the above structures, the Service also has an Immigration Center. The Immigration Center is a specialized institution for the reception and accommodation of foreigners who have been ordered by the decision of the competent authority in $\mathrm{BiH}$ to be placed under supervision under the Law.

Vranješ (2018) underlines that The Service for Foreigners has significant organizational and structural capacities for the implementation of migration and asylum policy, but only in the usual regime of migration and not in conditions of migration crises.

According to the Law on Asylum (2016), foreigners are protected by the principle of nonrefoulement from returning to a country where there is a real risk of death or execution, torture, inhuman or degrading treatment or punishment. In the asylum procedure, it examines the validity of the reasons for granting refugee status in $B \& H$ to an applicant who has serious reasons to face a real risk of persecution due to race, religion, nation, political opinion, or belonging to a particular social group if he returns to the country or in or country of usual residence. Furthermore, in the asylum application procedure in $\mathrm{B} \& \mathrm{H}$, special attention is paid to the examination of the existence of reasons for compliance with the principle of non-refoulment in the 
context of granting supplementary protection, subsidiary protection. The conditions for granting subsidiary protection to an alien are examined by the Ministry of Security - Asylum Sector in the asylum procedure after it is determined that the foreigners do not meet the conditions for granting refugee status. In this regard, subsidiary protection is granted to a foreigner who does not qualify for refugee status if there are serious grounds for believing that returning to the country of origin or country of habitual residence will confront a real risk of severe violation of human rights and fundamental freedoms.

Furthermore, the Ministry of Human Rights and Refugees of $\mathrm{B} \& \mathrm{H}$ is responsible for monitoring, implementation, promotion, and protection of personal and collective human rights and, among other things, for the care of the rights and issues of refugees and persons under subsidiary protection in $\mathrm{B} \& \mathrm{H}$ after determining their status (Law on Ministries and Other Administrative Bodies of B\&H, 2009).

\subsection{Short observational view on the migrant crisis}

All international migrations can be divided into two categories: involuntary or forced (also called refugee movements), and voluntary or free (also called economic migrations) based on the motivation behind the migrations. Involuntary or forced migration refers essentially to refugee flows, where for reasons of natural disaster, war, civil war, ethnic, religious or political persecution people are forced to flee their homes (Bali, 2008, p. 475).

Institution of the Human Rights Ombudsman of Bosnia and Herzegovina emphasizes the fact that Bosnia and Herzegovina is facing the process of the so-called mixed migrations. Therefore, there are foreigners who are looking for better living conditions or the so-called economic migrants (citizens of Pakistan, Iran, Iraq, Morocco, Tunisia, Algeria, Libya, Afghanistan) and foreigners seeking asylum/persons under international legal protection (Syria) (Institution of the Human Rights Ombudsman of Bosnia and Herzegovina, 2019).

Schmeidl (2016) researched the migration of 3.9 million Afghan international migrants which are displaced across borders due to the conflict and violence in Afghanistan that has grown and subsided since the 1970s. Major migration corridors include Bangladesh-India, Afghanistan-Pakistan, India-Pakistan and Nepal-India; however, it is essential to note that these corridors are all quite distinct, reflecting a range of historical and contemporary economic, security and cultural factors. There are millions of Bangladeshi and Nepalese labour migrants currently working in India, for example, 
primarily in the informal sector as construction labourers and domestic workers. In contrast, the India-Pakistan corridor in part reflects the mass displacement following the 1947. Partition of India and Pakistan (Srivastava and Pandey, 2017). Regions including Europe, Northern America and Oceania are among the most preferred destinations of irregular migrants from Southern Asia (McAuliffe and Jayasuriya, 2016). For example, migrants from Southern Asia heading to Western Europe are primarily smuggled through Central Asia and the Russian Federation, as well as through the Middle East into the Western Balkans (Sengupta, 2018).

An analysis of data for the last two years shows that the largest number of illegal migrants from Pakistan, Afghanistan, Iraq, Morocco, Syria, Bangladesh, Algeria, and Iran, account for $87 \%$ of the total number of illegal migrants in 2018. and 2019. Also, in 2019. there is a significant increase in the number of citizens of Egypt, Morocco, Bangladesh, Algeria, Eritrea, Tunisia, Turkey, Nepal, Albania, Afghanistan and Pakistan, as well as a decrease in the number of citizens of Iran, Libya, Palestine, Syria, and Yemen. This indicates that most people who enter illegally the territory of B\&H are mostly economic migrants and that the trend of economic migration is increasing. Taking into account that Pakistani citizens are the most represented among migrants, the Council of Ministers of $B \& H$ determined the Proposal of the Readmission Agreement between the Council of Ministers of Bosnia and Herzegovina and the Government of the Islamic Republic of Pakistan and the Proposal of the Protocol between the $\mathrm{BiH}$ Ministry of Security and the Ministry of Interior of Pakistan (Atlantic Initiative, 2020). To understand the level of complexity, we will try to illustrate what is going on when a foreigner enters the territory of $\mathrm{B} \& \mathrm{H}$.

Speaking about obtaining asylum (refugee status and subsidiary protection), whose procedure is prescribed by Art. 19-51 of the Law on Asylum (2016), B\&H has a relatively liberal approach, harmonized with European regulations. What eventually attracts special attention is the fact that a person who has been granted refugee status can acquire B\&H citizenship without fulfilling the whole set of conditions (knowledge of language and script, renunciation of existing citizenship) if he/she has been a refugee in $\mathrm{B} \& \mathrm{H}$ continuously for five years before the application, according to Art. 12 . Furthermore, a foreigner may acquire B\&H citizenship, among other conditions, if he/she has been granted a residence permit on the territory of B\&H for at least three years before applying. Vranješ (2018) believes that the conditions set in this way create exceptional opportunities for migrants to obtain B\&H citizenship in a reasonably quick and easy way, which other countries do not allow even remotely, and states that this is a particular problem from the aspect of migrant crisis if migrants decide to stay in B\&H. 
A person who has expressed an intention to apply for asylum is issued a certificate of expressed intention to apply for asylum with a validity period of 14 days (the deadline provided by the Law on Asylum). Within the specified period, the foreigner must submit an asylum application to the Asylum Sector of the Ministry of Security of B\&H. According to Art. 32 of Law on Asylum expressing the intention to apply for asylum in $\mathrm{B} \& \mathrm{H}$ is an instrument that enables the right to residency on the territory of $\mathrm{B} \& \mathrm{H}$ during its validity.

Afterwards, Bosnia and Herzegovina provides a person with certificate of intent that lasts 14 days, which presents the legalization of residency. During that period, persons are sent to an appropriate centre or institution to apply for asylum or otherwise, they need to leave the country.

Graph 1: Asylum application trends (Ministry of Security BiH, 2020)

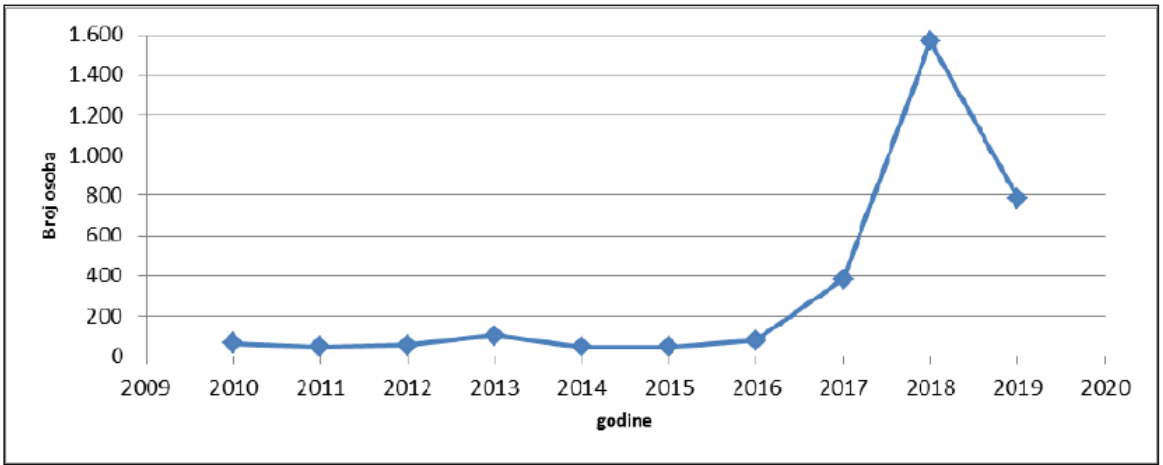

In previous graph 1., in 2017, there was a sharp increase in the number of asylum seekers by $382 \%$, where the largest number was recorded from Algeria, Pakistan, the Syrian Arab Republic, and Afghanistan (Ministry of Security BiH, 2020). In 2018, a total of 23,902 illegal migrants were reported to the Service for Foreigners. Out of a total of 23,902 registered illegal migrants, 22,499 persons expressed their intention to apply for asylum in B\&H in 2018. An asylum application was submitted by 1,567 persons or $7 \%$ of the total number of expressed intentions to apply for asylum in 2018. In 2019, a total of 29,302 illegal migrants were reported to the Service for Foreigners, which is an increase compared to 2018 by $22.59 \%$. It is also evident that the largest number of illegal migrants were recorded in the period April - October because, in that period, weather conditions are the most favourable for their movement. Out of a total of 29,302 registered illegal migrants, 27,769 persons expressed their intention to apply for asylum in $\mathrm{QiH}$ in 2019. Asylum applications were submitted by 784 persons or $3 \%$ 
of the total number of expressed intentions to apply for asylum in 2019 as shown in Graph 1., so it means that there is a decrease in the number of asylum seekers compared to 2018 by $50 \%$.

This trend is supported by previous secondary data showing the gap between the intention to seek asylum and the applications submitted, as well as from data indicating the number of rejected asylum applications due to the "disappearance" of asylum seekers. The search for asylum in the countries of the Western Balkans and escape after that, continues to grow as part of the well-known modus operandi when moving from Greece to other European Union countries (secondary migration flows) [Frontex, 2014, p. 16]. It is necessary to consider that increased powers for Frontex and further eventual tightening border controls will not stop people coming to Europe. Such measures will simply divert migrants to less well-policed entry points and increase their reliance on people smugglers, as Hampshire (2015) noticed. According to Ministry of Security B\&H (2020), the difference between the number of expressed intentions to apply for asylum and submitted asylum applications presents a direct indicator of the abuse of the asylum system in B\&H by legalizing illegal residency in B\&H. In other words, migrants express intent to seek asylum in $\mathrm{B} \& \mathrm{H}$ for a certain period of time and then use that for illegal departure to EU countries.

\section{BURDEN OF BOSNIA AND HERZEGOVINA VERSUS SECURITY THREATS AND RISKS}

When some issue becomes an object of security concern, it is "presented as an existential threat to a designated referent object", which leads to the securitization and justification the use of extraordinary measures to handle them (Buzan et al., 1998, p. 21). The securitization of migration, a view of migrants as terrorists and criminals, Huysmans explains, is related to a broader politicization in which immigrants and asylum-seekers are portrayed as a challenge to the protection of national identity and welfare provisions (2000), or in the case for B\&H presented as a security challenge. Due to political disagreements, $\mathrm{B} \& \mathrm{H}$ finds it challenging to dig up a solution to manage the crisis effectively.

The primary goal of controlling migration movements in $\mathrm{B} \& \mathrm{H}$ is to establish effective control over the entry, stay and movement of foreigners on state territory while ensuring all guaranteed human rights and freedoms of persons under the legal jurisdiction of Bosnia and Herzegovina (Ministry of Security of Bosnia and Herzegovina, 2016). 
These are mainly foreigners who entered or are entering $\mathrm{B} \& \mathrm{H}$ without any identification documents, in places that are not intended for crossing the state border, and they move from one state to another in violation of the legal regulations of the state they are entering, that is, against the will of the bodies of the state whose territory they are entering. Most of these persons have expressed their intention to seek asylum, although, for them, B\&H is mostly a country of transit (Institution of the Human Rights Ombudsman of Bosnia and Herzegovina, 2019).

Given that migrants can conceal their real identity and country of origin during migratory movements, it is questionable how obvious the threat is that perpetrators of various crimes, as well as terrorists, can take advantage of such benefits and infiltrate migrants and use their routes to switch to countries where they plan to carry out terrorist attacks. Genc (2017) reveals that migrations are securitized in the EU by the use of three related themes on internal security, cultural security and the crisis of the welfare state. Further, he states that these themes have been used to depict migrants as potential contributors to terrorist activities and organized crime; as a threat to the cultural identity of society because of their different cultural background; and as people who reap the benefits of the welfare system illegitimately and who commit welfare fraud to exploit the system. EUROPOL (2016) points out that the continued immigration pressure on the EU, combined with previous terrorist attacks in Europe, raises excellent concerns that the routes of illegal migrants could be used for the return of radicalized foreign fighters to the EU. Mullins also points to the problem of terrorist infiltration among refugees and asylum seekers, who have arrived in Europe since 2011 and are responsible for carrying out at least 13 terrorist attacks in 7 European countries (2019).

Having in mind the geopolitical position of $\mathrm{B} \& \mathrm{H}$, the specificity of the green border, and risk analysis, various security threats are identified: threats in the field of border checks and threats in the field of state border control (Council of Ministers of B\&H, 2019). The B\&H Border Police conducts border checks at 83 international and border crossings, which is why about $85 \%$ of police officers are engaged at border crossings, while the rest control the border zone. Extraordinary engagement of people also includes logistical support: providing vehicles for patrols, fuel, surveillance, and monitoring equipment, accommodation facilities, food, as well as other costs. According to the systematization, where 2,426 police officers are planned, the $B \& H$ Border Police lacks 401 police officers to perform regular activities in border control (Border Police, 2020).

Also, the challenges faced by the B\&H Border Police in the field of border checks are lack of necessary infrastructure at some border crossings, an insufficient number of 
police officers working on the first and second line of border checks, insufficient technical equipment with specialized technical equipment for detecting forged documents and inspection hidden spaces on vehicles, an increase in the number of misuse of documents, (travel documents, visas, identity cards), and the current migrant crisis (Council of Ministers of B\&H, 2019).

The Service for Foreigners' Affairs is responsible for initiating and conducting the procedure for establishing the identity of foreigners in $\mathrm{B} \& \mathrm{H}$. If the procedure for determining the identity of foreigners has been initiated by the Border Police of B\&H or the police, and it cannot complete it within six hours, the Service for Foreigners should be notified. A foreigner who does not have proof of identity is obliged to give a statement of his identity to the Office for Foreigners' Affairs and to provide biometric data. Further, a foreigner whose identity cannot be determined immediately or there are grounds for doubting the veracity of his allegations or whose identity cannot be determined with certainty within six hours of being brought to the official premises, shall be placed under surveillance and expelled from $B \& H$, which is prescribed by Art. 14 of the Law on Foreigners (2015). ${ }^{12}$ If a foreigner "crosses or attempts to cross the state border outside the border crossing open for international traffic or outside the border crossing intended for traffic between $\mathrm{B} \& \mathrm{H}$ and neighbouring countries, it is considered that he tried to cross the state border illegally", as Art. 16 prescribes.

A significant number of foreigners, more precisely migrants, are in illegal residence on the territory of $\mathrm{B} \& \mathrm{H}$ and an effective solution must be found for them. According to the data of the Ministry of Security of B\&H during 2018, a total of 4,489 persons were detected in an attempt to cross the border of B\%H illegally, while in 2019, an increase of $30.52 \%$ was recorded and amounted to 5,859 persons (2020). During 2018, there were 617 (at entrance 232 + at exit 385) registered persons in illegal crossing of the state border, and outside the border crossing (border zone) 3,872 (at entrance 2,660+ at exit 1,212) persons. The following graph shows the structure of detected illegal migrants. Therefore, having this numbers in mind, it is of great importance to equip border officers with equipment for detecting illegal migrants in means of transport and to improve the fixed and portable technical surveillance system of the land border

12 The Law on Foreigners in Art. 1 regulates the conditions and procedure for entry of foreigners into $\mathrm{B} \& \mathrm{H}$, visa and visa-free regime, travel documents for foreigners, a residency of foreigners in Bosnia and Herzegovina, removal from $B \& H$, reception and supervision, as well as competencies of authorities in the application of this Law, misdemeanours, and penalties for misdemeanours committed in violation of the provisions of this Law, and other issues related to the residency of foreigners in $\mathrm{B} \& \mathrm{H}$. 
between border crossings, which are especially endangered from the aspect of illegal migration and human trafficking.

Graph 2: Overview of detected illegal border crossings in 2018 and 2019 classified by country (Ministry of Security of $\mathrm{BiH}, 2020$ )

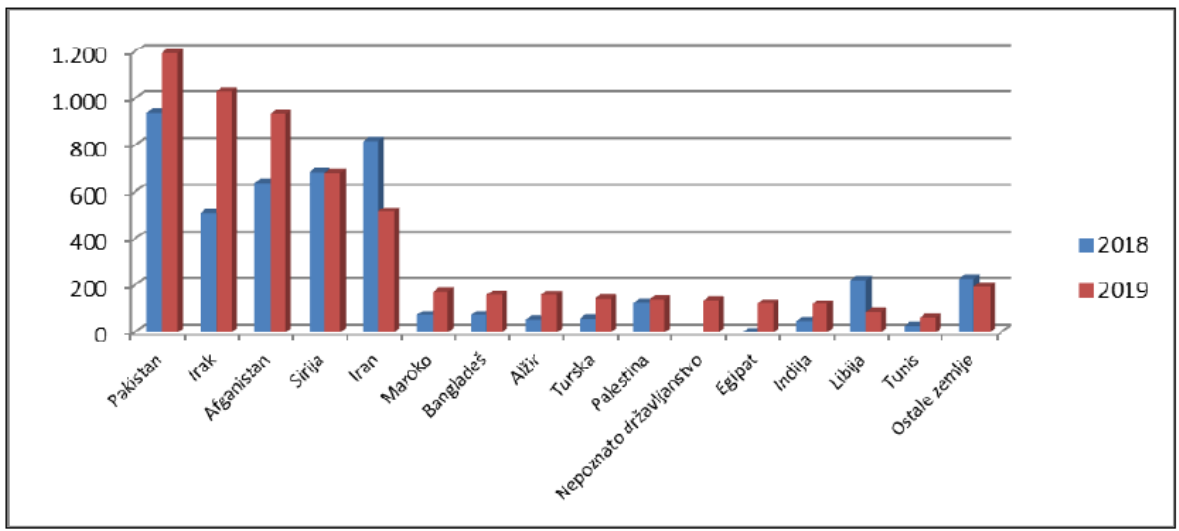

\section{BURDEN OF BOSNIA AND HERZEGOVINA VERSUS HUMANITARIAN THREATS AND RISKS}

The accommodation of migrants and refugees is a significant challenge. B\&H has a limited number of reception and transit centres, and none at entry and exit points at the border, although there are plans to open additional facilities. Generally speaking, accommodation for migrants, refugees and asylum seekers varies from place to place and includes many ad-hoc solutions involving national regulatory authorities and various international, humanitarian and non-governmental organizations led by the International Organization for Migration. Therefore, it can be state that migration policy is not harmonized. The burden of the migrant crisis should be evenly distributed throughout Bosnia and Herzegovina, which is not the case now, given the heavy workload of Una-Sana Canton. In an interview published in October 2020, the Minister of Security, Mr Selmo Cikotić, announces an increase in accommodation capacities for migrants (Atlantic Initiative, 2020).

Based on the inter-agency report for August (UNHCR, 2020) and the offered crosssection of the situation from the previous interview, in order to determine at least approximately some of the migration trends that $B \& H$ is currently facing, we will take a look at the data on the movements of foreigners across the state border of $B \& H$. 
During August 2020, B\&H authorities registered the arrival of 2,618 migrants and asylum-seekers to the country, bringing the total to almost 11,600 (UNHCR, 2020). Firstly, of that number of 6,531 persons were in formal accommodation, while 3,250 3,800 persons were outside.

\section{Picture 1: Review of reception centres (UNHCR, 2020)}

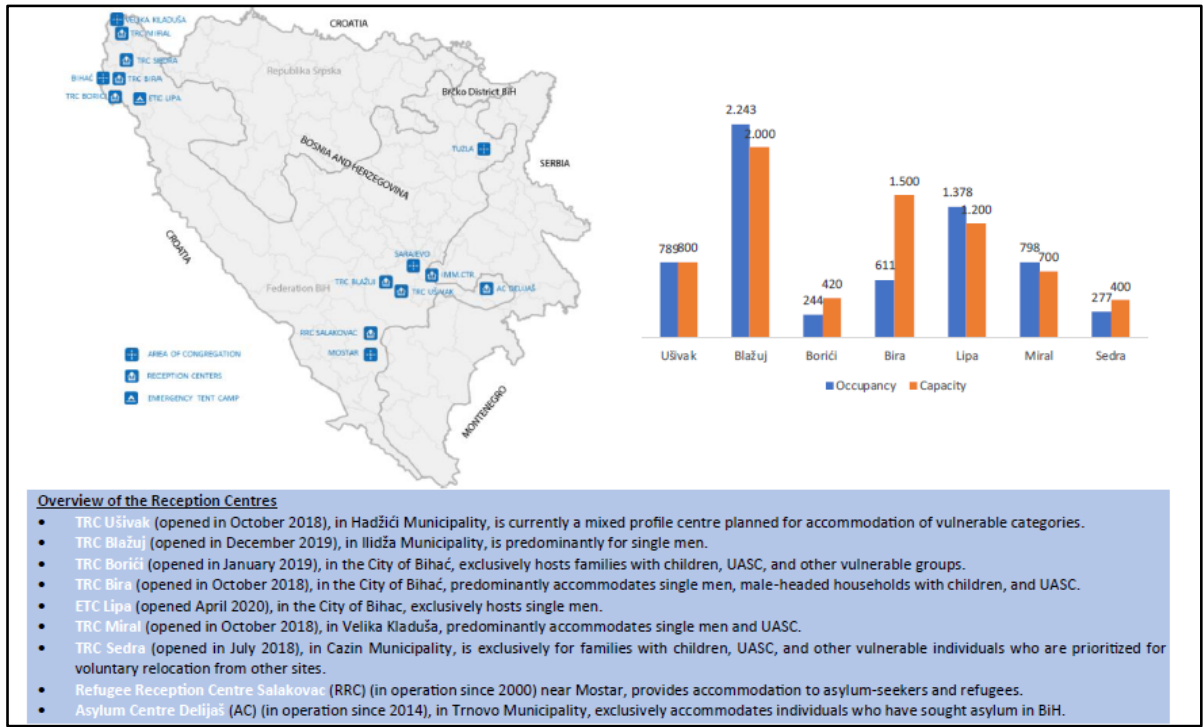

To take adequate measures for migrants before the brutal winter conditions arrive, the Government of the Federation of $\mathrm{B} \& \mathrm{H}$, at its 145th emergency session held on November 11, 2019, decided to provide the Ministry of Security with centres for the free use of migrants (Atlantic Initiative, 2020).

The former barracks "Ušivak", in the municipality of Hadžići, was opened in October 2018. and had 800 seats, with a separate space for families, women and unaccompanied minors. The Service for Foreigners' Affairs manages the temporary reception in cooperation with the IOM. In December 2019, 1,316 people stayed in the facility, which means that there was no adequate accommodation for 516 people. By August 2020, the situation had improved in Ushivka, when 789 migrants were housed, which was in line with its capacity. However, on October 20, 2020, the stay of 938 people was recorded, which again oversaturated the facility. Given this, the question arises about the quality of the living conditions of migrants in that place. 
A similar example is in the former barracks "Blažuj", which is located in the municipality of Ilidža. The capacity of the Blažuj barracks is 2,000 seats. On December $31,2019,427$ people stayed in this facility. However, in August, 2,243 people stayed in that facility, and on October 20, 2020, the number was 2,350 people.

In the Una-Sana Canton, the Bira facility has 1,500 capacities, of which 611 have been filled. Borići can accommodate 420 people based on capacity, and in August 2020, 244 people stayed in the facility. It is similar to Sedra, which has a capacity of 400 and 277 people. The "Lipa" tent camp was formed in response to the needs arising from the emergency caused by the COVID-19 disease, in order to relocate migrants who were staying in abandoned and dilapidated buildings in the area of the city of Bihać. The total capacity of the camp is 1,200 people, and it is intended for accommodation of men. On October 20, 2020, 1,365 people stayed in the camp (Atlantic Initiative, 2020). The situation is different when it comes to the reception centres Miral and Lipa, where there are more migrants than the conditions allow. Thus, 798 people stayed in Miral in August 2020 , and the capacity is 700 . In Lipa, there is a capacity of 1,200 , and 1,378 people are accommodated.

\section{CONCLUSION}

It is clear that human migrations are and will always be present. However, it is inevitable that their causes, manifestations, scope, directions and directions, and thus the effects on human, national and international security, will change. The United Nations special rapporteur on migration Felipe González Morales said, at the end of his visit to $B \& H$ on October 1. 2019, that 'the increased flow of migrants has exposed the significant institutional and coordination weakness of relevant authorities at different levels of BiH' (EPRS, 2019).

Migrants are not a threat to national security, but primarily a humanitarian issue. If they pose a security threat, it is in the domain of public order and peace, low-intensity crime, with the possibility of infiltrating persons prone to committing terrorist acts.

Bosnia and Herzegovina has well-designed institutional capacities to address the current humanitarian and security challenges of the migrant crisis, but a further strengthening of Bosnia and Herzegovina's migration policy is needed. The institutions of Bosnia and Herzegovina will have a much more critical, demanding and responsible role, especially in terms of establishing even more effective control over the migrations and primarily operational work to prevent irregular migration. This will require additional institutional, staffing and technical strengthening primarily of the Service for 
Foreigners and $\mathrm{B} \& \mathrm{H}$ Border Police and other institutions dealing with these phenomena, in order to effectively respond to the challenges of new regional trends. Inadequate border protection and inadequate equipment of security services and institutions that should deal with migrant issues pose a serious threat. This can only be achieved through a clear, organizational-productive and prognostic-based migrant policy. Bosnia and Herzegovina must urgently take all necessary measures to prevent a humanitarian crisis from unfolding and ensure effective coordination, border management and capacity. A strong, constant and optimally articulated diplomatic action towards the institutions in Brussels and towards the countries from which migrants mostly arrive is an absolute priority.

\section{REFERENCES}

1. Ahmetašević, N. (2020). Brutalnost kao nova normalnost. https://ba.boell.org/bs/2020/10/08/brutalnost-kao-nova-normalnost

2. Ambrosini, M. (2018). Irregular Immigration in Southern Europe: Actors, Dynamics and Governance. Palgrave Macmillan.

3. Atlantic Initiative Center for Security and Justice Research (2020). How to manage migration in Bosnia and Herzegovina. No.04.

4. Bali, S. (2008). Population movements. In: Wiliams, P. (Ed.), Security Studies: an introduction, $1^{\text {st }}$ ed. (474-480). Routledge.

5. Bobić, M., \& Šantić, D. (2018). Sigurnost EU vs sigurnosti migranata: Srbija na Balkanskoj migracijskoj ruti. Forum za sigurnosne studije, 2 (2), 219-246.

6. Bonifazi, C. Crisci, M. Marini, C., \& Sanmartin Orti, A. (2014). The Balkans and the EU: Recent trends of a Mediterranean migration. South East European Journal of Political Science, 2(3), 110-125.

7. Border Police BiH (2020). Report of the Border Police for 2019. Border Police BiH.

8. Bourbeau, P. (2011). The Securitization of Migration: A study of movement and order. Routledge.

9. Buzan, B., Waever, O., \& Wilde J. (1998). Security: A New Framework for Analysis. Lynne Rienner.

10. Connor, P., \& J.M. Krogstad (2018). Many worldwide oppose more migration both into and out of their countries. Pew Research Center. www.pewresearch.org/fact-tank/2018/12/10/manyworldwide-oppose-moremigration-both-into-and-out-of-their-countries/.

11. Council of Ministers of $\mathrm{BiH}$ (2019). Strategy of integrated border management in Bosnia and Herzegovina for the period 2019-2023. Council of Ministers of $\mathrm{BiH}$

12. Decision on the Establishment of the Coordination Body for Migration Issues in Bosnia and Herzegovina, Official Gazette of BiH, No. 10/13, 64/13, 01/14, 20/16 \& 83/17 (2017). 
13. Diamant, J., \& K. J. Starr (2018). Western Europeans vary in their nationalist, antiimmigrant and anti-religious minority attitudes. Pew Research Center. www.pewresearch.org/facttank/2018/06/19/western-europeans-vary-in-theirnationalist-antiimmigrant-and-antireligious-minority-attitudes/.

14. European Commission (2018b). Compilation of Data, Situation, and Media Reports on Children in Migration. European Commission. www.ec.europa.eu/newsroom/document.cfm?doc_id=40299.

15. European Parliamentary Research Service (2019). The situation on migrants in Bosnia and Herzegovina. https://www.europarl.europa.eu/thinktank/en/document.html?reference=EPRS BRI(2019)644174

16. EUROPOL-INTERPOL (2016). Migrant Smuggling Networks: Joint Europol-Interpol Report. file:///C:/Users/SPS/Downloads/ep-ip_report_executive_summary.pdf

17. Frontex (2014). Western Balkans Annual Risk Analysis. https://frontex.europa.eu/publications/?category=riskanalysis

18. Genç, D. (2017). A paradox in EU migration management. Journal for Labour and Social Affairs in Eastern Europe. Special Issue: Migration Waves in Eastern Europe (1990-2015). 237-248.

19. Hampshire, J. (2015). Europe's Migration Crisis. Political Insight, 6(3). https://doi.org/10.1111/2041-9066.12106.

20. Huysmans, J. (2000). The European Union and the securitization of migration. Journal of Common Market Studies, 38(5): 751-777.

21. Institution of the Human Rights Ombudsman of Bosnia and Herzegovina (2019). Special report on the situation in the field of migration in Bosnia and Herzegovina. Institution of the Human Rights Ombudsman of Bosnia and Herzegovina

22. International Organization for Migration (2012). Moving to Safety: Migration Consequences of Complex Crises, Background Paper for the International Dialogue on Migration. https://publications.iom.int/fr/books/international-dialoguemigration-ndeg20-moving-safety-migration-consequences-complex-crises

23. International Organization for Migration (2016). Key Migration Terms. http://www.iom.int/key-migration-terms

24. IOM (2020). World 2020. https://publications.iom.int/system/files/pdf/wmr_2020.pdf

25. Law on Asylum, Official Gazette of BiH, No. 11/16 and 16/16 (2016).

26. Law on Citizenship, Official Gazette of BiH, No. 4/97,13/97,41/02,6/03, 14/03 (2003).

27. Law on Foreigners, Official Gazette of BiH, No. 88/15 (2015).

28. Law on Ministries and Other Administrative Bodies of BiH, Official Gazette of BiH, No. 5/03, 42/03, 26/04, 42/04, 45/06, 88/07, 35/09 \& 103/09 (2009). 
29. Law on Service for Foreigners Affairs, Official Gazette of BiH, No. 54/05 \& 36/08 (2008).

30. Law on the Council of Ministers, Official Gazette of BiH, No. 30/03, 42/03, 81/06, 76/07, 81/07, 94/07 \& 24/08 (2008).

31. Lhoumeaum, F. (2019). Rethinking the European Union-Western Balkans cooperation on fighting organized crime in light of new challenges brought by the migration crisis. CSS.

32. Lindley A. (2014). Exploring crisis and migration: concepts and issues. In Lindley A. (Ed.), Crisis and Migration, Critical perspectives, 1st ed. (1-15). Routledge studies in development, mobilities and migration.

33. Maksimović, D. (2020). Migrantska kriza u BiH: građani prijete blokadama. https://www.dw.com/hr/migrantska-kriza-u-bih-gra\%C4\%91ani-prijeteblokadama/a-54758965

34. Martin, S., Weerashinghe, S.S., \& Taylor, A. (2014). Humanitarian Crises and Migration: Causes, Consequences and Responses (1st ed). Routledge. https://doi.org/10.4324/9780203797860

35. Mazzola, A., \& Martiniello, M. (2020). Le Covid-19 brise les fragiles solidarités avec les réfugiés. https://theconversation.com/le-covid-19-brise-les-fragilessolidaritesavec-les-refugies-134737

36. McAuliffe, M. (2018) The nexus between forced and irregular migration: Insights from demography. In Hugo, G., Abbasi-Shavazi, J., \& Kraly, E. P. (Eds.), The Demography of Refugee and Forced Migration. Springer.

37. Ministry of Security BiH (2016). Migration and asylum strategy and Action Plan for the period 2016-2020. Ministry of Security.

38. Ministry of Security BiH (2020). Migration profile of Bosnia and Herzegovina for 2019. Ministry of Security, Immigration Sector.

39. Mullins, S. (2019). Jihadist Infiltration of Migrant Flows to Europe: Perpetrators, Modus Operandi and Policy Implications, Palgrave Macmillan-

40. Schmeidl, S. (2016). Determinants of Displacement from Post-2014 Afghanistan. Australian National University. http://demography.anu.edu.au/ afghanmigration-conference/participants

41. Sengupta, A. (2018). Southern Africa. In Triandafyllidou, A., \& McAuliffe, M. (Eds.), Migrant Smuggling Data and Research: A global review of the emerging evidence base, Volume 2. IOM, Geneva. https://publications.iom.int/books/migrantsmuggling-data-and-research-global-reviewemerging-evidence-base-volume-2

42. Sokol, A. (2019). Kako je došlo do gašenje portala Antimigrant? MC Online. https://www.media.ba/bs/magazin-novinarstvo/kako-je-doslo-dogasenjaportala-antimigrant 
43. Tatalović, S., \& Malnar, D. (2016). Migracijska i izbjeglička kriza u Evropi: države balkanskog migracijskog pravca između sekuritizacije i humanitarizma, Međunarodni problemi, Institut za međunarodnu politiku i privredu, 4/2016, 293.

44. Terzić, A. (2018). Zoran Galić: Složeniju situaciju s migrantima na granici BiH očekujemo dolaskom toplijih dana. https://www.aa.com.tr/ba/balkan/zorangali\%C4\%87-slo\%C5\%BEeniju-situaciju-s-migrantima-na-granici-biho\%C4\%8Dekujemo-dolaskom-toplijih-dana/1350807

45. UNHCR (2020). Bosnia and Herzegovina: Interagency Response to Mixed Movement. Monthly situation report: October 2018. UNHCR.

46. UNHCR (2020). Bosnia and Herzegovina: interagency response to mixed movement. Monthly situation report: august 2020. UNHCR.

47. Vale G. (2018). Migrants, the EU passes the buck to Bosnia and Herzegovina. Osservatorio balcani e caucaso transeuropa. https://www.balcanicaucaso.org/eng/Areas/Bosnia-Herzegovina/Migrants-theEUpasses-the-buck-to-Bosnia-and-Herzegovina-190986

48. Vranješ, M. (2018). Regulatorni okvir i upravni kapaciteti bosne i hercegovine za migrantsku krizu. Zbornik radova sa Regionalne konferencije "regionalna saradnja u suzbijanju prekograničnog kriminala: savremeni izazovi terorizma i migrantske krize", Zbornik radova, 315-331.

\section{About the author}

Kenan Hodžić, MA, teaching assistant, Faculty of Criminalistics, Criminology and Security Studies, University of Sarajevo. E-mail: khodzic@fkn.unsa.ba. 